\title{
Effect of Temperature-Shift and Temperature-Constant Cultivation on the Monacolin K Biosynthetic Gene Cluster Expression in Monascus sp.
}

\author{
Lin Lin, Changlu Wang*, Zhenjing Li, Huijia Wu and Mianhua Chen \\ Key Laboratory of Food Nutrition and Safety, College of Food Engineering and Biotechnology, \\ Tianjin University of Science and Technology, No. 29, 13th Avenue, TEDA, Tianjin 300457, PR China \\ Received: April 5, 2016 \\ Accepted: October 12, 2016
}

\begin{abstract}
Summary
In this study, the effects of temperature-shift (from 30 to $25^{\circ} \mathrm{C}$ ) and temperature-constant (at $30^{\circ} \mathrm{C}$ ) cultivation on the mass of Monascus fuliginosus CG-6 mycelia and concentration of the produced monacolin $\mathrm{K}(\mathrm{MK})$ were monitored. The expression levels of the MK biosynthetic genes of $M$. fuliginosus CG-6 at constant and variable culture temperatures were analysed by real-time quantitative polymerase chain reaction (RT-qPCR). The total protein was collected and determined by liquid chromatography-electrospray ionisation with tandem mass spectrometry (LC-ESI-MS/MS). Results showed that the maximum mycelial mass in temperature-shift cultivation was only $0.477 \mathrm{~g}$ of dry cell mass per dish, which was lower than that in temperature-constant cultivation ( $0.581 \mathrm{~g}$ of dry cell mass per dish); however, the maximum concentration of $\mathrm{MK}$ in temperature-shift cultivation $(34.5 \mu \mathrm{g} / \mathrm{mL})$ was 16 times higher than that in temperature-constant cultivation at $30{ }^{\circ} \mathrm{C}(2.11 \mu \mathrm{g} / \mathrm{mL})$. Gene expression analysis showed that the expression of the MK biosynthetic gene cluster at culture temperature of $25^{\circ} \mathrm{C}$ was higher than that at $30^{\circ} \mathrm{C}$, which was similar to the trend of the MK concentration, except for individual $M K B$ and $M K C$ genes. Analysis of differential protein expression revealed that 2016 proteins were detected by LC-ESI-MS/MS. The expression level of efflux pump protein coded by the $M K I$ gene exhibited the same upregulated trend as the expression of $M K I$ in temperature-shift cultivation. Temperature-shift cultivation enhanced the expression of proteins in the secondary metabolite production pathway, but suppressed the expression of proteins involved in the mycelial growth.
\end{abstract}

Key words: Monascus fuliginosus CG-6, monacolin K, temperature, protein analysis, gene analysis

\section{Introduction}

Monascus spp. are traditional food fungi that can produce many kinds of secondary metabolites, including pigments, $\gamma$-aminobutyric acid and monacolins (1). Monascus spp. contain statins, which can be used for alternative statin treatment. In particular, monacolin $\mathrm{K}$ (MK, also named lovastatin, mevinolin, and Mevacor $\left.{ }^{\circledR}\right)$ is a strong 5-hydroxy-3-methylglutaryl-coenzyme A (HMG-CoA) reductase inhibitor. HMG-CoA reductase is an enzyme that mediates the rate-limiting reaction of cholesterol biosyn- thesis. MK can inhibit cholesterol biosynthesis and lower blood cholesterol levels in both humans and animals (2). Therefore, it is known as an anticholesterol and antihypotensive agent (3).

The culture environment is crucial for filamentous fungi to produce secondary metabolites. Different culture temperatures can influence the production of secondary metabolites. Ahn et al. (4) proved that the pigment yield at $25^{\circ} \mathrm{C}$ is 10 times higher than that at $30^{\circ} \mathrm{C}$, because the lower temperature $\left(25^{\circ} \mathrm{C}\right)$ can reduce the fungal growth 
rate. Tsukahara et al. (5) separated the growth phase and lovastatin production phase by lowering the temperature from 30 to $25{ }^{\circ} \mathrm{C}$. Monascus pilosus NBRC 4520 was cultured at $30{ }^{\circ} \mathrm{C}$ for 4 days, followed by additional 17 days of incubation at $25{ }^{\circ} \mathrm{C}$. Results showed that M. pilosus hardly produced $\mathrm{MK}$ during temperature-constant cultivation at $30{ }^{\circ} \mathrm{C}$, but efficient production was observed after lowering the culture temperature from 30 to $25{ }^{\circ} \mathrm{C}$. However, the reason why the shift in temperature led to high MK production remains unclear.

To improve our understanding of the action mechanism underlying MK production in Monascus sp. via temperature-shift cultivation, a detailed study of the effect of temperature-shift and temperature-constant cultivation on MK production and the possible mechanism is necessary. In this study, the mycelial mass and MK concentration during temperature-shift and temperature-constant cultivation were monitored. The expression levels of the MK biosynthetic genes were measured by real-time quantitative polymerase chain reaction (RT-qPCR). The protein expression of mycelia was analysed by LC-ESI-MS/ MS. This study aims to investigate the relationship between temperature and the MK biosynthetic gene cluster. Several secondary metabolites and metabolism growth-related proteins that differ in amounts during temperature-shift and temperature-constant cultivation were identified.

\section{Materials and Methods}

\section{Strains and culture conditions}

Preserved Monascus fuliginosus CG-6, bought from China Center of Industrial Culture Collection (CICC), was activated on malt extract agar for 6 days at $30{ }^{\circ} \mathrm{C}$. Spores were harvested with $2 \mathrm{~mL}$ of sterile water and inoculated into $100 \mathrm{~mL}$ of seed medium (in \%): glucose 6, peptone 2, $\mathrm{KH}_{2} \mathrm{PO}_{4} 1, \mathrm{NaNO}_{3} 1$ and $\mathrm{MgSO}_{4} \cdot 7 \mathrm{H}_{2} \mathrm{O} 0.5$ (Sinopharm Chemical Reagent Co., Ltd., Shanghai, PR China) in $250-\mathrm{mL}$ flasks. The culture was incubated at $30{ }^{\circ} \mathrm{C}$ for $48 \mathrm{~h}$ with shaking at $180 \mathrm{rpm}$. To measure the biomass and MK production by Monascus fuliginosus CG-6, $10 \%$ fungal liquid was inoculated on seed medium containing $4 \%$ cellophane agar and the mycelium was cultured at 30 ${ }^{\circ} \mathrm{C}$ for 6 days. The cultures were subsequently divided into two groups: one group was cultured at $30{ }^{\circ} \mathrm{C}$ for 15 days, and the other at $25{ }^{\circ} \mathrm{C}$ for 15 days. The spore concentration was adjusted to approx. $10^{6}$ spore/mL by haemocytometer.

\section{Determination of biomass}

The mycelium biomass at different culture temperatures was determined by removing the cellophane to recover the mycelia of the two groups. The biomass yield in solid seed culture medium was determined gravimetrically after drying at $50{ }^{\circ} \mathrm{C}$ overnight to a constant mass. The biomass was determined every 3 days. All samples were determined at least three times.

\section{Extraction and HPLC analysis}

The sample was dried and ground into a powder. Approximately $0.5 \mathrm{~g}$ of powder was extracted by $3 \mathrm{~mL}$ of 75
$\%$ ethanol for $30 \mathrm{~min}$ in an ultrasonic bath and then centrifuged at $2150 \times g$ (model Anke TDL-5-A; Shanghai Anting Scientific Instrument Factory Co., Ltd., Shanghai, PR China) for $15 \mathrm{~min}$. Samples were prepared in triplicate. The total supernatant was pooled and passed through 0.22- $\mu \mathrm{m}$ RC filters (ANPEL Laboratory Technologies Inc., Shanghai, PR China).

MK was detected by HPLC-DAD (Agilent Technologies, Chengdu, PR China) at $270 \mathrm{~nm}$. An Eclipse XDB-C18 column (4.6 mm $\times 150 \mathrm{~mm}, 5 \mu \mathrm{m}$; Agilent Technologies) was used at $25^{\circ} \mathrm{C}$, and isocratic elution was performed for $30 \mathrm{~min}$ using acetonitrile/water (containing $0.05 \%$ methanoic acid) 60:40, by volume at $1 \mathrm{~mL} / \mathrm{min}$. Standards from Sigma-Aldrich (St. Louis, MO, USA) were used. The MK concentration was determinated every 3 days. All experiments were performed in triplicate.

\section{Gene expression analysis with $R T-q P C R$}

The mycelia were obtained at two different culture temperatures $\left(25\right.$ and $\left.30^{\circ} \mathrm{C}\right)$ when the MK concentration peaked. Total mycelial RNA was extracted by Plant RNA kit (Omega, Shanghai, PR China), and cDNA was synthesised by PrimeScript 1st strand cDNA synthesis kit (Takara Bio Inc., Dalian, PR China) with Oligo dT Primer 15. RT-qPCR was conducted to monitor gene expression levels using the SYBR Premix Ex Taq II (Takara Bio Inc.). Primers for $M K A, M K B, M K C, M K D, M K E, M K F, M K$ $G, M K H$ and $M K I$ genes (GenBank accession no. DQ176595.1) (6) and the $\beta$-actin gene (GenBank accession no. AJ417880) (7) were designed by Primer Premier v. 5 software (8) to amplify a portion of the nine genes (Table 1). RT-qPCR was performed using Stratagen Mx3000P

Table 1 . The primers used in this study in RT-qPCR designed by Primer Premier v. 5 software (8)

\begin{tabular}{|c|c|c|}
\hline Primer & Sequence $\left(5^{\prime}-3^{\prime}\right)$ & Product size/bp \\
\hline$\beta$-actin-F & AGTCCAACAGGGAGAAGATG & \multirow{2}{*}{132} \\
\hline$\beta$-actin-R & CACCAGAGTCAAGCACGATA & \\
\hline$M K A-\mathrm{F}$ & GAACCATCGCCGACAAAT & \multirow{2}{*}{179} \\
\hline$M K A-\mathrm{R}$ & AACAAGGTCCAAGTCATCCAG & \\
\hline$M K B-\mathrm{F}$ & ACAGTGTAGAGGGAGGTGTAAG & \multirow{2}{*}{159} \\
\hline$M K B-\mathrm{R}$ & AATCGGAGACCGTGTATGT & \\
\hline$M K C-F$ & TGAGCCGAAGAAGTACGACC & \multirow{2}{*}{152} \\
\hline$M K C-\mathrm{R}$ & CCTTGGAGGCGAAGAACC & \\
\hline$M K D-F$ & ATGCGGGAGGAGGTAGGCT & \multirow{2}{*}{198} \\
\hline$M K D-\mathrm{R}$ & CCGATTCGGGAAATGATGC & \\
\hline$M K E-\mathrm{F}$ & ATCCTCCACGAGCCTTGCC & \multirow{2}{*}{194} \\
\hline$M K E-\mathrm{R}$ & GCCGCTATGTCTCCCTGAAC & \\
\hline$M K F-\mathrm{F}$ & AAACGGAGAAGCAGATGAACC & \multirow{2}{*}{103} \\
\hline$M K F-\mathrm{R}$ & ATCCСАCСАAGCССАAAA & \\
\hline$M K G-F$ & ACACGCCGAGACGGTAGA & \multirow{2}{*}{161} \\
\hline MK G-R & CGAGCCCGAATACAAAGG & \\
\hline$M K H-F$ & GTCTGCCCACTCCTCCTT & \multirow{2}{*}{190} \\
\hline MK H-R & СTTCAACCCGAATCTCCAC & \\
\hline$M K I-F$ & CAGAACCCAAACACCACC & \multirow{2}{*}{109} \\
\hline$M K I-\mathrm{R}$ & TGATCTCACTTGCGTTAGAAT & \\
\hline
\end{tabular}


(Agilent Technologies) with the following cycling program: $95^{\circ} \mathrm{C}$ for $30 \mathrm{~s}$, followed by a three-step PCR (40 cycles of denaturation at $95^{\circ} \mathrm{C}$ for $5 \mathrm{~s}$, annealing at $58^{\circ} \mathrm{C}$ for $30 \mathrm{~s}$, and extension at $72{ }^{\circ} \mathrm{C}$ for $30 \mathrm{~s}$ ) and denaturation curve analysis $\left(95^{\circ} \mathrm{C}\right.$ for $15 \mathrm{~s}$, annealing at $58^{\circ} \mathrm{C}$ for $30 \mathrm{~s}$, collecting the denaturation curve from 58 to $95^{\circ} \mathrm{C}$, finally at $95^{\circ} \mathrm{C}$ for $\left.15 \mathrm{~s}\right)$. Relative expression levels were calculated by the $2^{-\Delta C q}$ method (9). All values were normalised using the reference expression level of the $\beta$-actin gene. The gene expression level of the mycelia cultured at $30^{\circ} \mathrm{C}$ was used as a calibrator.

\section{Sample preparation and protein extraction}

Monascus fuliginosus CG-6 samples were ground in liquid nitrogen and lysed in $8 \mathrm{M}$ urea supplemented with $1 \%$ nonyl phenoxypolyethoxyethanol (NP-40) (Beyotime, Shanghai, PR China), $2 \mathrm{mM}$ ethylenediaminetetraacetic acid (EDTA) (Sinopharm Chemical Reagent Co., Ltd.), $5 \mathrm{mM}$ dithiothreitol (DTT) (Thermo Fisher Scientific, Shanghai, PR China) and protease inhibitor cocktail. The samples were lysed by sonication with 12 short bursts of $10 \mathrm{~s}$ followed by intervals of $30 \mathrm{~s}$ for cooling. Unbroken cell and debris were removed by centrifugation (Backman Coulter, Beijing, PR China) at $4{ }^{\circ} \mathrm{C}$ and $2960 \times g$ for $10 \mathrm{~min}$. The protein content in the supernatant was determined with a 2D Quant kit (GE Healthcare, Beijing, PR China). An equal amount of protein was reduced with $5 \mathrm{mM}$ DTT and alkylated with $25 \mathrm{mM}$ iodoacetamide (IAM) (Sinopharm Chemical Reagent Co., Ltd.). The precipitate was washed three times with cold acetone after centrifugation, suspended in $0.1 \mathrm{M}$ tetraethylammonium bromide (TEAB) (Sinopharm Chemical Reagent Co., Ltd.) and digested with trypsin (Promega, Madison, WI, USA) at an enzyme-to-substrate ratio of 1:50 for $12 \mathrm{~h}$ at $37^{\circ} \mathrm{C}$. Digestion was terminated with $1 \%$ trifluoroacetic acid (TFA) (Thermo Fisher Scientific) and the resulting peptides were purified with a Strata X C18 SPE column (Phenomenex, Guangzhou, PR China) and dried in Scanvac (Labogene, Shanghai, PR China).

\section{LC-ESI-MS/MS analysis by $Q$ Exactive plus}

The lyophilised peptides were resuspended in buffer $\mathrm{A}(2 \%$ acetonitrile (ACN) and $0.1 \%$ formic acid (FA)) (Thermo Fisher Scientific), loaded onto an Acclaim PepMap 100 C18 trap column $(75 \mu \mathrm{m} \times 0.02 \mathrm{~cm}$; Dionex, Shanghai, PR China) by Ultimate 3000 nano ultra-performance liquid chromatograph (UPLC) (Dionex), and eluted onto an Acclaim PepMap rapid separation liquid chromatograph (RSLC) C18 analytical column $(75 \mu \mathrm{m} \times 0.25 \mathrm{~cm}$; Dionex). A 90-minute linear gradient was run at $0.3 \mathrm{~mL} / \mathrm{min}$, starting from 8 to $35 \% \mathrm{~B}(80 \% \mathrm{ACN}$ and $0.1 \% \mathrm{FA})$, followed by 4 -minute gradient to $80 \% \mathrm{~B}$, and maintained at $80 \% \mathrm{~B}$ for $8 \mathrm{~min}$.

The peptides were subjected to a nanospray ionisation source in $\mathrm{Q}$ Exactive plus mass spectrometer (Thermo Fisher Scientific) coupled online to UPLC. Intact peptides were detected in the Orbitrap (Thermo Fisher Scientific) at a resolution of 70000 and the $\mathrm{m} / \mathrm{z}$ scan range from 350 to $1400 \mathrm{Da}$. The 20 most intense peptides above a threshold ion counts of $2 \mathrm{E} 4$ were sequentially isolated and frag- mented for MS/MS using $27 \%$ normalised collision energy (NCE) (Thermo Fisher Scientific). The dynamic exclusion was $30 \mathrm{~s}$. Ion fragments were detected in the Orbitrap (Thermo Fisher Scientific) at a resolution of 17 500. The applied electrospray voltage was $2.0 \mathrm{kV}$. Automatic gain control was used to prevent overfilling of the ion trap; 3E6 and 1E5 ions were accumulated for the generation of MS and MS/MS spectra, respectively.

\section{Database search}

MaxQuant software (10) with an integrated Andromeda (11) search engine v. 1.3.0.5 was used to identify the protein. Tandem mass spectra were searched against a database of predicted Monascus purpureus strain YY-1 (12) proteins (7491 sequences). Trypsin/P was specified as a cleavage enzyme allowing up to two missing cleavages, three modifications per peptide and five charges. Mass error was set to $6 \mathrm{ppm}$ for precursor ions and $0.02 \mathrm{Da}$ for fragment ions. Carbamidomethylation on Cys was specified as fixed modification. Oxidation on Met and acetylation on the protein $\mathrm{N}$-terminal were specified as variable modifications. False discovery rate thresholds for protein, peptide and modification site were specified at 0.01 . The minimum peptide length was 6 . The protein hit of 'reversed', 'contaminant ' or 'only identified by site' was removed.

\section{Protein quantitation}

Label-free quantification of identified proteins was performed by MaxLFQ (13) integrated into MaxQuant software. In addition to the parameters set above, LFQ quantification was enabled by checking 'Match between runs ', 'LFQ' and 'iBAQ'.

After MaxQuant processing, the proteinGroup.txt file was loaded and analysed by Perseus v. 1.5.0.31 software (14). Briefly, the LFQ intensity values of two samples were logarithmically transformed. The missing LFQ value was replaced by normal distribution to simulate the background LFQ intensity level. The relative protein ratio was calculated by exponential transformation of the different values between the logarithmically transformed LFQ values of two samples.

\section{Graphics programme}

Origin v. 8 software (15) was used in this study to draw the figures. Data were subjected to ANOVA using Excel v. 10 (16).

\section{Results and Discussion}

\section{Mycelial biomass}

Biomass was measured at an interval of 3 days (Fig. 1). Cell growth was slow in temperature-shift cultivation. The maximum biomass was only $0.477 \mathrm{~g}$ of dry cell mass per dish on the 18th day of dish fermentation. The maximum dry cell mass in temperature-constant cultivation was $0.581 \mathrm{~g}$ per dish on the 21st day, which was higher than that in temperature-shift cultivation. 


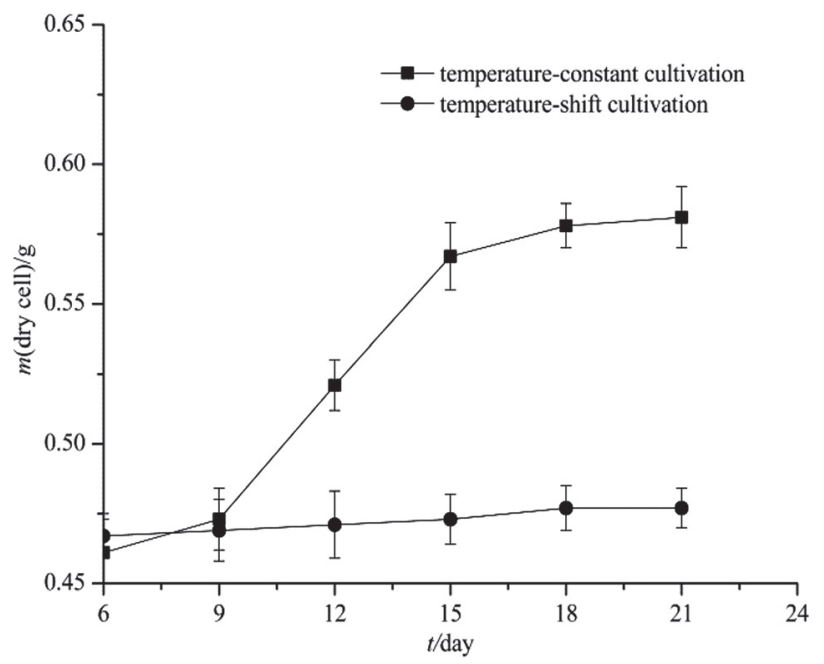

Fig. 1. Cell growth by dry cell mass in temperature-constant (at $30^{\circ} \mathrm{C}$ for 21 days) and temperature-shift (at $30^{\circ} \mathrm{C}$ for 6 days and at $25{ }^{\circ} \mathrm{C}$ for 15 days) cultivations. The data are represented as the mean value \pm standard error of the mean $(\mathrm{SEM})(N=3)$

\section{Determination of monacolin K content}

Monacolin $\mathrm{K}$ is a well-known secondary metabolite of Monascus sp. because of its ability to lower total cholesterol, low-density lipoprotein cholesterol and triglycerides in the plasma of hyperlipidaemic patients (17). Mulder et al. (18) showed that the culture temperature is an important environmental factor for the increase of MK titers. The linear regression equation of the standard curve was obtained according to the concentration and corresponding peak area and was determined to be:

$$
\mathrm{y}=63.48 \mathrm{x}, \mathrm{R}^{2}=0.996
$$

The different culture temperatures contributed to different concentrations of MK, and the results are shown in Fig. 2. The MK concentration initially increased and then

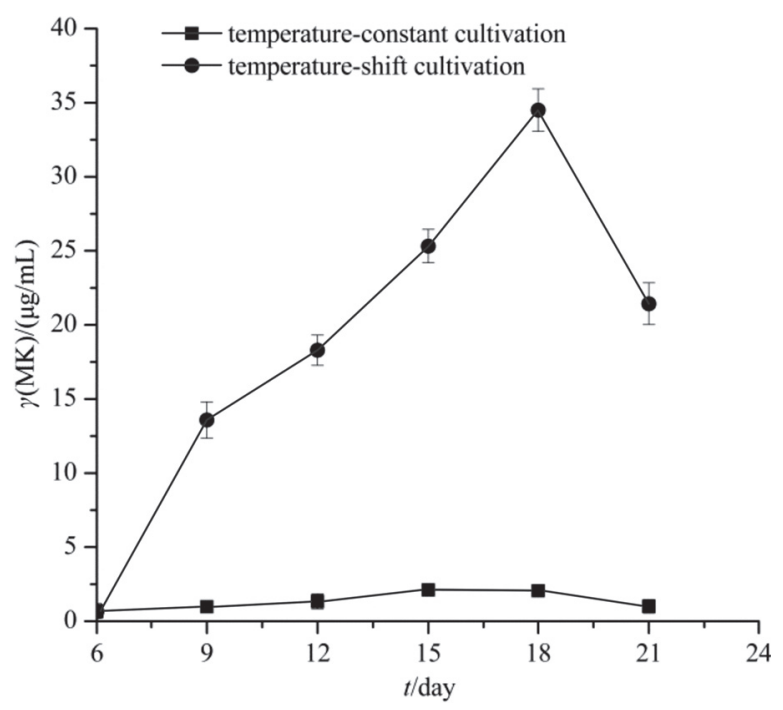

Fig. 2. Monacolin $\mathrm{K}(\mathrm{MK})$ concentration in temperature-constant (at $30^{\circ} \mathrm{C}$ for 21 days) and temperature-shift (at $30{ }^{\circ} \mathrm{C}$ for 6 days and at $25^{\circ} \mathrm{C}$ for 15 days) cultivations. The data are represented as the mean value \pm SEM $(N=3)$ decreased during both cultivation types at both temperatures. In temperature-constant cultivation it was much lower than that in temperature-shift cultivation. MK was hardly produced in temperature-constant cultivation at $30{ }^{\circ} \mathrm{C}$. The highest concentration of MK in temperature-shift cultivation was observed on the 18th day, whereas that in temperature-constant cultivation occurred on the 15th day. Compared with the highest concentration of MK in temperature-constant cultivation at $30^{\circ} \mathrm{C}(2.11 \mu \mathrm{g} /$ $\mathrm{mL})$, the one in temperature-shift cultivation $(34.5 \mu \mathrm{g} / \mathrm{mL})$ was 16 times higher. This result was in agreement with the findings of Tsukahara et al. (5), who reported that MK was hardly produced in temperature-constant cultivation at $30^{\circ} \mathrm{C}$, but efficient production was observed after lowering the temperature from 30 to $25^{\circ} \mathrm{C}$.

\section{Expression of monacolin K biosynthetic genes}

To study the effect of temperature on MK production, the MK biosynthetic gene cluster was selected for evaluating the gene expression level by RT-qPCR (Fig. 3). Gene expression of mycelia cultured at $25^{\circ} \mathrm{C}$ was higher than of those cultured at $30^{\circ} \mathrm{C}$, which showed a similar variation trend compared with Fig. 2, except for $M K B$ and $M K$ $C$ genes. The 2-methylbutyryl-CoA and monacolin $\mathrm{J}$ are the precursors for the biosynthesis of MK. At high concentrations they can stimulate its production by promoting $M K F$ expression, which encodes transesterase, but also cause feedback inhibition of $M K B$ and $M K C$ genes. Therefore, the expression levels of $M K B$ and $M K C$ genes were lower than of those cultured at $30^{\circ} \mathrm{C}$. The biosynthetic pathway of MK was described by Manzoni and Rollini (19). The expression of the MK biosynthetic gene cluster increased in parallel with the concentration of produced MK. Notably, the expression of the MK I gene in temperature-shift cultivation was 1.65 times higher than that in temperature-constant cultivation, which exhibited

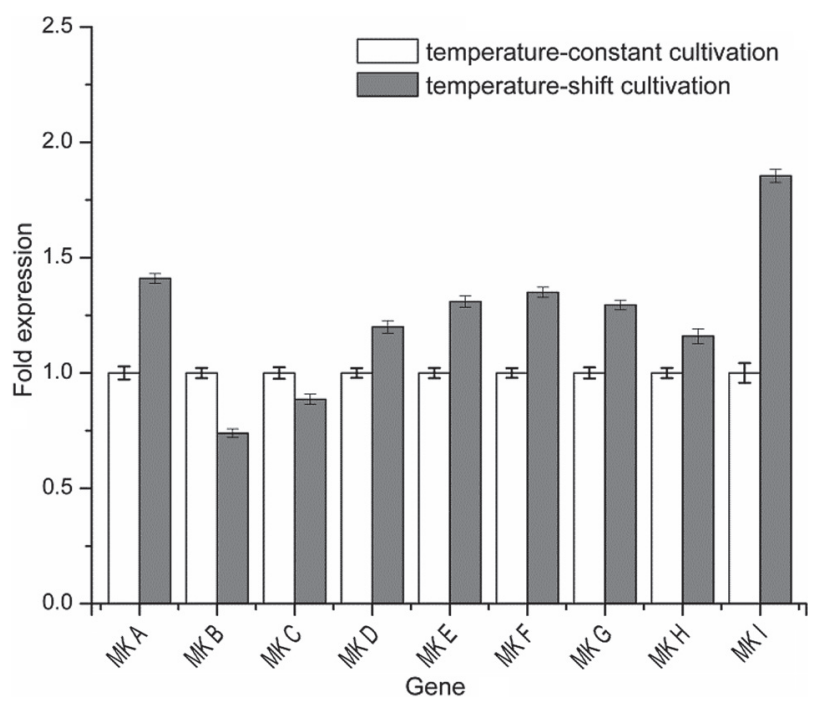

Fig. 3. Expression of monacolin K (MK) biosynthetic genes in temperature-constant and temperature-shift cultivations. All values were normalised using the expression level of the $\beta$-actin gene as a reference and the expression level of mycelia cultivated at $30{ }^{\circ} \mathrm{C}$ as a calibrator. Data were expressed as the relative mRNA level for each gene and represented as the mean value $\pm \operatorname{SEM}(N=3)$ 
the greatest change in the MK biosynthetic gene cluster (Fig. 3). This result indicated that temperature-shift cultivation could improve MK production by enhancing the expression of the MK biosynthetic gene cluster. The cultured environment can regulate the production of secondary metabolites by regulating metabolite biosynthesis in the gene cluster; for example, blue light stimulates citrinin production by upregulating the expression of citrinin biosynthesis genes (20). Therefore, a low culture temperature $\left(25^{\circ} \mathrm{C}\right)$ could enhance the expression of the MK biosynthesis gene cluster, which finally led to the increase in MK production. A low temperature $\left(25^{\circ} \mathrm{C}\right)$ could enhance the expression of the protein that plays a role in the secondary metabolite production pathway, and suppress the expression of the protein that maintained mycelial growth.

\section{The differential protein expression of mycelia at different culture temperatures}

A total of 2016 proteins were detected by LC-ESI-MS/ MS, and the protein content of the Monascus fuliginosus CG-6 mycelia cultivated at $30{ }^{\circ} \mathrm{C}$ was used as the control group. The cut-off of twofold variation was used as the

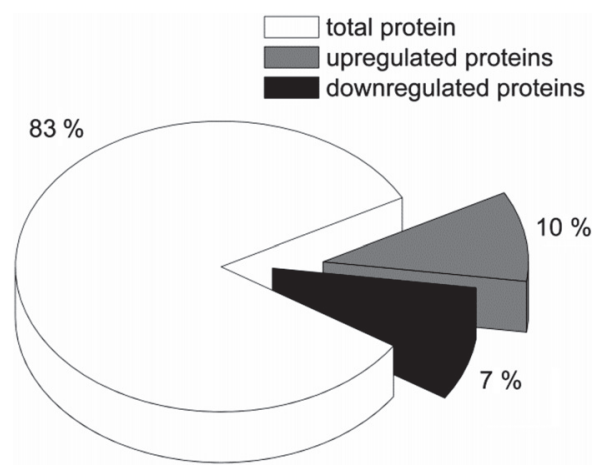

Fig. 4. Pie chart of protein expression changes. Protein content of Monascus fuliginosus CG-6 mycelia cultured at $30{ }^{\circ} \mathrm{C}$ was used as the control group and cut-off of 2 -fold variation was used as judgment index judgment index, and the results showed 240 upregulated proteins and 180 downregulated proteins. The pie chart of protein expression changes is shown in Fig. 4. The upregulated proteins accounted for $10 \%$ of the total protein, whereas the downregulated proteins amounted to $7 \%$ of the total protein.

A portion of the upregulated proteins is listed in Table 2 (21). Among these identified proteins, the evm.model.C4.388 drew attention primarily because it was the efflux pump protein coded by the MK I gene with UniProt protein ID of Q3S2U5 (6). The expression level of efflux pump proteins in temperature-shift cultivation was 1.35 times higher than that in temperature-constant cultivation (Table 2). Chiang et al. (22) showed that efflux pump proteins can transport polyketide out of the cell. The expression level of efflux pump proteins exhibited the same trend as the MK I gene. Therefore, temperature-shift cultivation could enhance the expression levels of the $M K I$ gene and efflux pump proteins, leading to the transport of polyketide MK out of the cell.

In addition to efflux pump proteins, several upregulated proteins play well-known functional roles in metabolites produced by microorganisms. Such metabolites include evm.model.C3.887, which is an ent-kaurene oxidase. Ent-kaurene oxidase can catalyse the oxidation reaction from ent-kaurene to ent-kaurenoic acid, which is the intermediate of gibberellin biosynthesis (23). Gibberellin is a phytohormone that can remove the growth limitation of plants, and it is a secondary metabolite of certain fungal species such as Gibberella fujikuroi, Penicillium resedanum and Fusarium sp. $(24,25)$. Evm.model.C8.204, described as pyruvate decarboxylase, is a key enzyme responsible for ethanol formation. It can convert the central metabolite pyruvate to acetaldehyde, and alcohol dehydrogenase can reversibly convert acetaldehyde to ethanol (26). It exists extensively in microorganisms such as Rhizopus oryzae, Gluconacetobacter diazotrophicus and Saccharomyces cerevisiae $(27,28)$. Pyruvate decarboxylase can accelerate metabolite ethanol production.

$\gamma$-Amino butyric acid (GABA) is a major inhibitory neurotransmitter of the mammalian central nervous sys-

Table 2. Significantly upregulated proteins of Monascus fuliginosus CG-6 mycelia cultivated at $25^{\circ} \mathrm{C}$ identified by LC-ESI-MS/MS

\begin{tabular}{lcccl}
\hline Protein ID & $\begin{array}{c}\text { No. of } \\
\text { matched } \\
\text { peptides }\end{array}$ & $\begin{array}{c}\text { Ratio of protein } \\
\text { expression levels } \\
\left(25^{\circ} \mathrm{C} / 30^{\circ} \mathrm{C}\right)\end{array}$ & $\begin{array}{c}\text { Gene } \\
\text { ontology } \\
(21)\end{array}$ & Function description \\
\hline evm.model.C2.326 & 3 & 30.96 & GO:0018342 & $\begin{array}{l}\text { Protein farnesyltransferase/geranylgeranyltransferase type-1 } \\
\text { subunit alpha }\end{array}$ \\
evm.model.C3.921 & 4 & 30.82 & GO:0055114 & L-arabinitol 4-dehydrogenase \\
evm.model.C2.668 & 7 & 24.93 & GO:0006464 & Probable E3 ubiquitin-protein ligase hulA \\
evm.model.C3.887 & 1 & 23.13 & GO:0020037 & Ent-kaurene oxidase \\
evm.model.C8.204 & 2 & 17.48 & GO:0030976 & Pyruvate decarboxylase \\
evm.model.C1.159 & 3 & 17.18 & GO:0055114 & Quinone oxidoreductase-like protein 2 homologue \\
evm.model.C1.548 & 4 & 13.02 & GO:0006221 & CTP synthase \\
evm.model.C5.371 & 4 & 12.99 & GO:0008152 & 4-coumarate-CoA ligase-like 1 \\
evm.model.C6.424 & 2 & 7.28 & GO:0019752 & Glutamate decarboxylase \\
evm.model.C4.388 & 1 & 1.35 & GO:0016021 & Efflux pump \\
\hline
\end{tabular}

The upregulated proteins were more than 2-fold compared to the mycelia cultivated at $30^{\circ} \mathrm{C}$, except for evm.model.C4.388 
Table 3. Significantly downregulated proteins of Monascus fuliginosus CG-6 mycelia cultivated at $25^{\circ} \mathrm{C}$ identified by LC-ESI-MS/MS

\begin{tabular}{|c|c|c|c|c|}
\hline Protein ID & $\begin{array}{c}\text { No. of } \\
\text { matched } \\
\text { peptides }\end{array}$ & $\begin{array}{l}\text { Ratio of protein } \\
\text { expression levels } \\
\left(25^{\circ} \mathrm{C} / 30^{\circ} \mathrm{C}\right)\end{array}$ & $\begin{array}{c}\text { Gene } \\
\text { ontology } \\
(21)\end{array}$ & Function description \\
\hline evm.model.C4.455 & 4 & 0.023 & GO:0006508 & Mitochondrial-processing peptidase subunit alpha \\
\hline evm.model.C6.692 & 2 & 0.034 & GO:0006486 & $\begin{array}{l}\text { Dolichyl-diphosphooligosaccharide-protein glycosyltransferase } \\
\text { subunit stt3 }\end{array}$ \\
\hline evm.model.C4.541 & 3 & 0.039 & GO:0008152 & Peroxisomal 3-ketoacyl-CoA thiolase \\
\hline evm.model.C2.114 & 2 & 0.056 & GO:0008152 & Tyrosinase \\
\hline evm.model.C5.746 & 3 & 0.083 & GO:0008152 & Mitochondrial 2-methylisocitrate lyase \\
\hline evm.model.C7.460 & 7 & 0.11 & GO:0046488 & Phosphatidylinositol 4-phosphate 5-kinase its3 \\
\hline evm.model.C4.802 & 3 & 0.15 & GO:0055114 & Putative acyl-CoA dehydrogenase AidB \\
\hline evm.model.C3.836 & 2 & 0.16 & GO:0055085 & ATP-dependent bile acid permease \\
\hline evm.model.C7.89 & 3 & 0.16 & GO:0006071 & Glycerophosphodiester phosphodiesterase GDE1 \\
\hline evm.model.C4.176 & 4 & 0.30 & GO:0006468 & cAMP-dependent protein kinase type 2 \\
\hline
\end{tabular}

The downregulated proteins were less than 0.5 -fold compared to the mycelia cultivated at $30^{\circ} \mathrm{C}$

tem. The glutamate decarboxylase (GAD), which has a protein ID evm.model.C6.424 in this study, is the main enzyme for producing GABA. GAD is an intracellular enzyme that is commonly used as a major catalyst in the trial biotransformation of GABA (29). GABA can be produced by many kinds of organisms such as plants and fungi (Trichoderma atroviride, Aspergillus oryzae and Monascus sp.) (30-32). The upregulated proteins play various roles, especially in secondary metabolite production.

Certain downregulated proteins (less than 0.5-fold compared with mycelia cultivated at $30{ }^{\circ} \mathrm{C}$ ) are listed in Table 3. Among these proteins, several have well-known functions in growth metabolism. The protein with the ID evm.model.C5.746 was described as 2-methylisocitrate lyase in mitochondria. The 2-methylisocitrate lyase is a subfamily of the isocitrate lyase superfamily, which can catalyse the cleavage of isocitrate to glyoxylate and succinate. The glyoxylate pathway is important for the growth of microorganisms on fatty acids, acetate, ethanol and amino acids (33). The glyoxylate cycle and isocitrate lyase are widely distributed among archaea, bacteria and fungi $(34,35)$. Evm.model.C4.802 was described as acyl-CoA dehydrogenase (ACAD), which can catalyse the $\alpha, \beta$-dehydrogenation of acyl-CoA esters in fatty acid and amino acid catabolism. The ACADs are mitochondrial flavoenzymes involved in fatty acid and amino acid catabolism, and they can produce ATP to aid organism growth (36). The function description of evm.model.C4.176 is cAMP-dependent protein kinase A (PKA), which can mediate the cAMP reaction in eukaryotic cells (37). PKA belongs to the serine-threonine protein kinase superfamily and participates in the control of various cellular processes (38). Among the downregulated proteins, several proteins act on growth metabolism.

\section{Conclusions}

In this study, Monascus fuliginosus CG-6 was cultured under temperature-constant $\left(30^{\circ} \mathrm{C}\right.$ for 21 days) and temperature-shift $\left(30{ }^{\circ} \mathrm{C}\right.$ for 6 days and $25^{\circ} \mathrm{C}$ for 15 days) conditions. The mycelial mass and monacolin $\mathrm{K}(\mathrm{MK})$ concen- tration at different culture temperatures were measured. Results showed that temperature-constant cultivation at 30 ${ }^{\circ} \mathrm{C}$ could enhance the Monascus fuliginosus CG-6 dry cell mass growth, but the MK concentration was 16 times lower than that during temperature-shift cultivation.

This study is the first to relate the expression of MK biosynthetic genes with MK production in Monascus sp. Gene expression analysis showed that gene expression of mycelia cultivated at $25^{\circ} \mathrm{C}$ was higher than that at $30^{\circ} \mathrm{C}$, which was similar to the trend observed with the MK concentration, except for $M K B$ and $M K C$ genes. The results also revealed that the expression of the $M K I$ gene during temperature-shift cultivation was 1.65 times higher than that during temperature-constant cultivation. The total protein of mycelia under two different temperatures was collected and analysed by LC-ESI-MS/MS. The efflux pump protein coded by the $M K I$ gene was found in the upregulated proteins, which demonstrated the same upregulation trend with the $M K I$ gene. However, the other proteins coded by the other genes of the MK biosynthesis gene cluster could not be measured because only one complete genome sequence of Monascus sp. exists. Among the upregulated proteins, we found that several proteins played various important roles, especially in secondary metabolite production, such as ent-kaurene oxidase, pyruvate decarboxylase and GAD. Several downregulated proteins act on growth metabolism, such as 2-methylisocitrate lyase, ACADs and PKAs, which play essential roles in the growth of microorganisms. The results of protein expression corresponded with the dry cell mass growth and MK concentrations, which suggested that a low temperature $\left(25^{\circ} \mathrm{C}\right)$ stimulated the organism to produce secondary metabolites, but a high temperature $\left(30^{\circ} \mathrm{C}\right)$ promoted mycelial growth.

\section{Acknowledgements}

This work was supported by the National Natural Science Foundation of China (grant nos. 31171729 and 31330059). We gratefully thank Xin Li (Protein T (Tianjin) Biotechnology Co. Ltd., Tianjin, PR China) for his technical assistance in mass spectrometry analysis. 


\section{References}

1. Wang C, Chen D, Chen M, Wang Y, Li Z, Li F. Stimulatory effects of blue light on the growth, monascin and ankaflavin production in Monascus. Biotechnol Lett. 2015;37:1043-8. http://dx.doi.org/10.1007/s10529-014-1763-3

2. Wang JJ, Lee CL, Pan TM. Improvement of monacolin $\mathrm{K}$, $\gamma$-aminobutyric acid and citrinin production ratio as a function of environmental conditions of Monascus purpureus NTU 601. J Ind Microbiol Biotechnol. 2003;30:669-76. http://dx.doi.org/10.1007/s10295-003-0097-2

3. Singgiha M, Saraswaty V, Ratnaningrum D, Priatni S, Damayanti S. The influence of temperature and ethanol concentration in monacolin $\mathrm{K}$ extraction from Monascus fermented rice. Procedia Chem. 2014;9:242-7. http://dx.doi.org/10.1016/j.proche.2014.05.029

4. Ahn J, Jung J, Hyung W, Haam S, Shin C. Enhancement of Monascus pigment production by the culture of Monascus sp. J101 at low temperature. Biotechnol Progr. 2006;22:338-40. http://dx.doi.org/10.1021/bp050275o

5. Tsukahara M, Shinzato N, Tamaki Y, Namihira T, Matsui T. Red yeast rice fermentation by selected Monascus sp. with deep-red color, lovastatin production but no citrinin, and effect of temperature-shift cultivation on lovastatin production. Appl Biochem Biotechnol. 2009;158:476-82. http://dx.doi.org/10.1007/s12010-009-8553-8

6. Chen YP, Yuan GF, Hsieh SY, Lin YS, Wang WY, Liaw LL, Tseng CP. Identification of the mokH gene encoding transcription factor for the upregulation of monacolin $\mathrm{K}$ biosynthesis in Monascus pilosus. J Agric Food Chem. 2010;58: 287-93.

http://dx.doi.org/10.1021/jf903139x

7. Perez-Campo F M, Nicaud J M, Gaillardin C, Dominguez A. Cloning and sequencing of the LYS1 gene encoding homocitrate synthase in the yeast Yarrowia lipolytica. Yeast. 1996; 12:1459-69.

http://dx.doi.org/10.1002/(SICI)1097-0061(199611)12:14<1459: :AID-YEA26>3.0.CO;2-M

8. Abd-Elsalam KA. Bioinformatic tools and guideline for PCR primer design. Afr J Biotechnol. 2003;2:91-5. http://dx.doi.org/10.5897/AJB2003.000-1019

9. Martinez-Yanes C, Xu HK. Strong convergence of the CQ method for fixed point iteration processes. Nonlinear Anal Theor. 2006;64:2400-11. http://dx.doi.org/10.1016/j.na.2005.08.018

10. Cox J, Mann M. MaxQuant enables high peptide identification rates, individualized p.p.b.-range mass accuracies and proteome-wide protein quantification. Nat Biotechnol. 2008; $26: 1367-72$ http://dx.doi.org/10.1038/nbt.1511

11. Cox J, Neuhauser N, Michalski A, Scheltema RA, Olsen JV, Mann M. Andromeda: a peptide search engine integrated into the MaxQuant environment. J Proteome Res. 2011;10: 1794-805. http://dx.doi.org/10.1021/pr101065j

12. Yang Y, Liu B, Du X, Li P, Liang B, Cheng X, et al. Complete genome sequence and transcriptomics analyses reveal pigment biosynthesis and regulatory mechanisms in an industrial strain, Monascus purpureus YY-1. Sci Rep. 2015;5:Article no. 8331. http://dx.doi.org/10.1038/srep08331

13. Cox J, Hein MY, Luber CA, Paron I, Nagaraj N, Mann M. Accurate proteome-wide label-free quantification by delayed normalization and maximal peptide ratio extraction, termed MaxLFQ. Mol Cell Proteomics. 2014;13:2513-26. http://dx.doi.org/10.1074/mcp.M113.031591

14. Cox J, Mann M. 1D and 2D annotation enrichment: a statistical method integrating quantitative proteomics with com- plementary high-throughput data. BMC Bioinformatics. 2012; 13(Suppl 16):S12.

http://dx.doi.org/10.1186/1471-2105-13-S16-S12

15. Topaloglu AK, Reimann F, Guclu M, Yalin AS, Kotan LD, Porter KM, et al. TAC3 and TACR3 mutations in familial hypogonadotropic hypogonadism reveal a key role for Neurokinin B in the central control of reproduction. Nat Genet. 2009;41:354-8.

http://dx.doi.org/10.1038/ng.306

16. Mélard G. On the accuracy of statistical procedures in Microsoft Excel 2010. Computation Stat. 2014;29:1095-128. http://dx.doi.org/10.1007/s00180-014-0482-5

17. Wolter S, Golombek M, Hammerschmidt A, Schwede F, Genieser HG, Seifert R. Activation of cGMP-dependent protein kinase I $\alpha$ and cAMP-dependent protein kinase $\mathrm{A}$ isoforms by cyclic nucleotides. BMC Pharmacol. 2011;11 Suppl 1:P76. http://dx.doi.org/10.1186/1471-2210-11-S1-P76

18. Mulder KC, Mulinari F, Franco OL, Soares MS, Magalhães BS, Parachin NS. Lovastatin production: from molecular basis to industrial process optimization. Biotechnol Adv. 2015; 33:648-65.

http://dx.doi.org/10.1016/j.biotechadv.2015.04.001

19. Manzoni M, Rollini M. Biosynthesis and biotechnological production of statins by filamentous fungi and application of these cholesterol-lowering drugs. Appl Microbiol Biotechnol. 2002;58:555-64. http://dx.doi.org/10.1007/s00253-002-0932-9

20. Wang C, Yang H, Chen M, Wang Y, Li F, Luo C, et al. Real-time quantitative analysis of the influence of blue light on citrinin biosynthetic gene cluster expression in Monascus. Biotechnol Lett. 2012;34:1745-8. http://dx.doi.org/10.1007/s10529-012-0962-z

21. Gene Ontology Consortium. The gene ontology (GO) project in 2006. Nucleic Acids Res. 2006;34 Suppl 1:D322-6. http://dx.doi.org/10.1093/nar/gkj021

22. Chiang YM, Szewczyk E, Davidson AD, Keller N, Oakley BR, Wang CC. A gene cluster containing two fungal polyketide synthases encodes the biosynthetic pathway for a polyketide, asperfuranone, in Aspergillus nidulans. J Am Chem Soc. 2009;131:2965-70. http://dx.doi.org/10.1021/ja8088185

23. Miyazaki S, Katsumata T, Natsume M, Kawaide H. The CYP701B1 of Physcomitrella patens is an ent-kaurene oxidase that resists inhibition by uniconazole-P. FEBS Lett. 2011;585: 1879-83. http://dx.doi.org/10.1016/j.febslet.2011.04.057

24. Khan AL, Waqas M, Lee IJ. Resilience of Penicillium resedanum LK6 and exogenous gibberellin in improving Capsicum annuum growth under abiotic stresses. J Plant Res. 2015;128: 259-68. http://dx.doi.org/10.1007/s10265-014-0688-1

25. Hedden P, Sponsel V. A century of gibberellin research. J Plant Growth Regul. 2015;34:740-60. http://dx.doi.org/10.1007/s00344-015-9546-1

26. Thitiprasert S, Songserm P, Boonkong W, Sooksai S, Kodama K, Thongchul N. Manipulating pyruvate decarboxylase by addition of enzyme regulators during fermentation of Rhizopus oryzae to enhance lactic acid production. Appl Biochem Biotechnol. 2014;174:1795-809.

http://dx.doi.org/10.1007/s12010-014-1155-0

27. van Zyl LJ, Schubert WD, Tuffin MI, Cowan DA. Structure and functional characterization of pyruvate decarboxylase from Gluconacetobacter diazotrophicus. BMC Struct Biol. 2014;14:21-33.

http://dx.doi.org/10.1186/s12900-014-0021-1

28. Zhang Y, Liu G, Engqvist MKM, Krivoruchko A, Hallström $\mathrm{BM}$, Chen $\mathrm{Y}$, et al. Adaptive mutations in sugar metabolism restore growth on glucose in a pyruvate decarboxylase nega- 
tive yeast strain. Microb Cell Fact. 2015;14:116-26. http://dx.doi.org/10.1186/s12934-015-0305-6

29. Yeng ALY, Ab Kadir MS, Ghazali HM, Zaliha RN, Rahman RA, Saari N. A comparative study of extraction techniques for maximum recovery of glutamate decarboxylase (GAD) from Aspergillus oryzae NSK. BMC Res Notes. 2013;6:52634. http://dx.doi.org/10.1186/1756-0500-6-526

30. Nižňanský L', Kryštofová S, Vargovič P, Kaliňák M, Šimkovič M, Varečka L'. Glutamic acid decarboxylase gene disruption reveals signalling pathway(s) governing complex morphogenic and metabolic events in Trichoderma atroviride. A Van Leeuwenhoek. 2013;104:793-807. http://dx.doi.org/10.1007/s10482-013-9989-y

31. Seher Y, Filiz O, Melike B. Gamma-amino butyric acid, glutamate dehydrogenase and glutamate decarboxylase levels in phylogenetically divergent plants. Plant Syst Evol. 2013;299: 403-12. http://dx.doi.org/10.1007/s00606-012-0730-5

32. Su YC, Wang JJ, Lin TT, Pan TM. Production of the secondary metabolites $\gamma$-aminobutyric acid and monacolin $\mathrm{K}$ by Monascus. J Ind Microbiol Biotechnol. 2003;30:41-6. http://dx.doi.org/10.1007/s10295-002-0001-5

33. Campos-Garcia J, Diaz-Perez C, Diaz-Perez AL. Residues Asn214, Gln211, Glu219 and Gln221 contained in the subfamily 3 catalytic signature of the isocitrate lyase from Pseu- domonas aeruginosa are involved in its catalytic and thermal properties. World J Microbiol Biotechnol. 2013;29:991-9. http://dx.doi.org/10.1007/s11274-013-1258-8

34. Dunn MF, Ramírez-Trujillo JA, Hernandez-Lucas I. Major roles of isocitrate lyase and malate synthase in bacterial and fungal pathogenesis. Microbiology. 2009;155:3166-75. http://dx.doi.org/10.1099/mic.0.030858-0

35. Kondrashov FA, Koonin EV, Morgunov IG, Finogenova TV, Kondrashova MN. Evolution of glyoxylate cycle enzymes in Metazoa: evidence of multiple horizontal transfer events and pseudogene formation. Biol Direct. 2006;1:31-9. http://dx.doi.org/10.1186/1745-6150-1-31

36. Swigoňová Z, Mohsen AW, Vockley J. Acyl-CoA dehydrogenases: dynamic history of protein family evolution. Mol Evol. 2009;69:176-93. http://dx.doi.org/10.1007/s00239-009-9263-0

37. Bardales JR, Díaz-Enrich MJ, Villamarín A. Differential distribution of cAMP-dependent protein kinase isoforms in the mantle of the bivalve mollusc Mytilus galloprovincialis. J Mol Hist. 2009;40:251-9. http://dx.doi.org/10.1007/s10735-009-9236-z

38. Nigović B, Sertić M, Mornar A. Simultaneous determination of lovastatin and citrinin in red yeast rice supplements by micellar electrokinetic capillary chromatography. Food Chem. 2013;138:531-8.

http://dx.doi.org/10.1016/j.foodchem.2012.10.104 